\title{
UPAYA PENINGKATAN PRODUKSI KACANG TANAH (Arachis hypogaea L.) DENGAN APLIKASI MACAM DOSIS MIKORIZA DAN PHONSKA
}

\section{Efforts To Increase The Production Of Peanuts (Arachis Hypogaea L.) By Kind of dosage Application Mycorrhizae And Phonska}

\author{
Fitria Widyastuti, Ana Amiroh, dan M. Imam Amminudin \\ Fakultas Pertanian Universitas Islam Darul ‘Ulum Lamongan Jawa Timur \\ korespondensi : hermawanwidyastuti@gmail.com/anaamiroh@unisda.ac.id
}

\begin{abstract}
ABSTRAK
Di Indonesia, Kacang Tanah (Arachis hypogaea L) menjadi komoditas penting dan strategis. Menurunnya kesuburan tanah merupakan satu penyebab rendahnya produktivitas kacang tanah. Untuk mengatasi masalah kesenjangan antara produksi dan konsumsi dapat dilakukan dengan menggunakan pupuk hayati mikoriza dan pupuk phonska karena pupuk ini yang tepat diterapkan untuk mendukung pertumbuhan tanaman kacang tanah tersebut. Upaya meningkatan produksi kacang tanah dengan memanfaatkan cendawan mikoriza secara umum memberikan manfaat yang besar oleh kesuburan tanah dalam jangka waktu yang panjang. Penelitian ini dilaksanakan di Desa Sukodadi, Kecamatan Sukodadi, Kabupaten Lamongan. Ketinggian tempat \pm 6 meter di atas permukaan laut. Waktu penelitian ini dilaksanakan pada bulan Februari-April 2020. Penelitian ini menggunakan metode rancangan acak kelompok RAK yang disusun secara faktorial dengan dua faktor perlakuan yaitu Pupuk Mikoriza dan Pupuk Phonska. Faktor Pupuk Mikoriza terdiri dari 3 level yaitu: $100 \mathrm{~kg} / \mathrm{ha}, 200 \mathrm{~kg} / \mathrm{ha}$, dan $300 \mathrm{~kg} / \mathrm{ha}$. Faktor Pupuk Phonska terdiri dari 3 level yaitu: Tanpa pemberian phonska, $50 \mathrm{~kg} / \mathrm{ha}$, dan $100 \mathrm{~kg} / \mathrm{ha}$. Pengamatan parameter pertumbuhan dan produksi yang diamati meliputi Tinggi tanaman, Jumlah Daun, Berat Brangkasan Basah, Berat Brangkasan Kering, dan Berat Biji PerPetak. Pengamatan dilaksanakan mulai umur 14 hari setelah tanam lalu dilanjut 14 hari sekali. Data hasil dari penelitian sejak tanaman berumur 14 hari setelah tanam hingga akhir pengamatan, dianalisa dengan analisa sidik ragam dan dilanjutkan dengan Uji BNT 5\%. Hasil pengamatan dan perhitungan melalui analisa sidik ragam dapat ditarik kesimpulan bahwa yang memberikan produksi tinggi pada tanaman kacang tanah yaitu perlakuan pupuk mikoriza $200 \mathrm{~kg} / \mathrm{ha}$ dan pupuk phonska $100 \mathrm{~kg} / \mathrm{ha}$.
\end{abstract}

Kata kunci : mikoriza, peningkatan produksi, phonska, kacang tanah.

\section{ABSTRACT}

In Indonesia, Peanut (Arachis hypogaea L) has become an important and strategic commodity. Decreasing soil fertility is one of the causes of low peanut productivity. To overcome the problem of the gap between production and consumption, it can be done by using biological fertilizers of mycorrhizal and phonska fertilizers because these fertilizers are precisely applied to support the growth of these peanut plants. Efforts to increase peanut production by utilizing mycorrhizal fungi in general will provide great benefits for soil fertility in the long term. This research was conducted in Sukodadi Village, Sukodadi District, Lamongan Regency. \pm 6 meters above sea level. The study was conducted in February-April 2020. This study used a randomized block design method which was arranged factorial with two treatment factors, namely Mycorrhizal Fertilizer (M) and Phonska Fertilizer. Mycorrhizal Fertilizer Factor consists of 3 levels, namely: $100 \mathrm{~kg} / \mathrm{ha}, 200 \mathrm{~kg} / \mathrm{ha}$, and 300 $\mathrm{kg} / \mathrm{ha}$. Phonska Fertilizer Factor consists of 3 levels, namely: Without giving phonska, $50 \mathrm{~kg} / \mathrm{ha}$ and $100 \mathrm{~kg} / \mathrm{ha}$. The observed growth and production parameters included: plant height, number of leaves, weight of wet cage, weight of dry cage, and weight of seeds per plot. Observations were 
made from the age of 14 days after planting and continued once in 14 days. Research data from the age of the plant 14 days after planting to the end of the observation were analyzed by analysis of variance and continued with the 5\% LSD test. The results of observations and calculations through analysis of variance can be concluded that what gives high production to peanuts is the treatment of mycorrhizal fertilizer $200 \mathrm{~kg}$ / ha and phonska fertilizer $100 \mathrm{~kg} / \mathrm{ha}$.

Key words: micorrhiza, increased production, phonska, peanuts.

\section{PENDAHULUAN}

Kacang tanah adalah tanaman pangan yang mempunyai nilai ekonomi tinggi karena kandungan gizinya terutama protein dan lemak yang tinggi. Kebutuhan kacang tanah dari tahun ke tahun terus meningkat sejalan dengan bertambahnya jumlah penduduk, kebutuhan gizi masyarakat, Diversifikasi pangan, Serta meningkatkan kapasitas industri makanan di Indonesia (Siregar, et al, 2017).

Di Indonesia, saat ini Kacang Tanah (Arachis hypogaea $\mathrm{L}$ ) sudah menjadi komoditas penting dan strategis (Taufiq dan Kristono, 2015). Namun produktivitas kacang tanah di Indonesia masih rendah, yaitu sekitar 1,3ton/ha. Tingkat produktivitas hasil ini baru setengah dari potensi hasil dari Amerika Serikat, China, dan Argentina yang mencapai hingga 2,0ton/ha (Kristina, 2016). Menurut Mulyani (2006) bahwa semakin menurunnya kesuburan tanah merupakan penyebab rendahnya produktivitas kacang tanah. Beberapa hasil penelitian menunjukan bahwa penurunan kesuburan tanah dapat dipulihkan dengan aplikasi bahan organik (Sudiarso, 2007).

Ketergantungan petani terhadap pemberian pupuk kimia yang berlebihan dan dilakukan terus menerus dalam jangka waktu lama, yang menimbulkan permasalahan baru pada lahan tersebut. Oleh karena itu perlu upaya meningkatkan kualitas dan kuantitas produk pertanian yang mempunyai dasar ekologi, biologis, dan kesehatan, diantaranya dengan memanfaatkan kembali mikroorganisme yang bermanfaat bagi tanah.

Pupuk yang berbahan dasar mikroorganisme berguna sebagai agens hayati untuk mendukung pertumbuhan dan perkembangan tanaman menjadi lebih baik, menjadikan salah satu alternative untuk menekan penggunaan pupuk kimia. Selain itu penggunaan pupuk agens hayati mampu mengembalikan lagi keberedaan mikroorganisme didalam tanah.

Peran mikroriza pada tanaman proses simbiosis dapat menghemat sedikitnya 50\% kebutuhan pupuk P (Maryani dan Nelvia, 2009) penggunaan mikoriza secara umum akan memberikan manfaat yang besar untuk kesuburan tanah dalam jangka waktu yang panjang, terutama pada tanah-tanah yang kurang subur dan banyaknya unsur hara yang tidak dapat disediakan untuk tanaman atau juga untuk tanah-tanah yang mengalami kejenuhan pemupukan an-organik seperti jenuh unsur $P$ (Fitrianto, et al., 2014).

Budidaya kacang tanah cocok di daerah dengan curah hujan sedang. Penyinaran matahari penuh dibutuhkan saat perkembangan daun dan pembesaran buah. Budidaya kacang tanah efektif dilakukan oleh tanah gembur dengan kandungan unsur hara kalsium (Ca), nitrogen (N), kalium (K) dan pospat $(\mathrm{P})$ yang cukup. Derajat kesaman $(\mathrm{pH})$ ideal bagi tumbuhan ini sekitar 5-6,3. Tanah gembur dengan struktur ringan sangat baik untuk perkembangan ginofor, bakal buah yang tumbuh memanjang ke dalam tanah (Anonimous, 2013).

Hasil tanaman ditentukan oleh
hetersediaan unsur
Mempengaruhi dalam pertumbuhannya baik unsur hara makro seperti C, H, O, N, P, K, $\mathrm{Ca}, \mathrm{Mg}$, dan $\mathrm{S}$ serta unsur hara mikro seperti $\mathrm{Fe}, \mathrm{Zn}, \mathrm{Co}, \mathrm{Mn}, \mathrm{Mo}, \mathrm{Bo}$,

dan $\mathrm{Cl}$. Kacang tanah termasuk tanaman leguminosae yang mampu mengikat nitrogen dari udara. Kemampuannya mengikat nitrogen baru dimiliki pada umur 15-20 hari setelah tanam. 
Tujuan penyusunan artikel ilmiah ini yaitu untuk mengetahui respon pengaruh micorrhiza dan pupuk phonska tentang upaya peningkatan produktivitas tanaman kacang tanah. Selain itu, dengan adanya pengembangan dan peningkatan aplikasi mikoriza sebagai pupuk agens hayati, dapat dijadikan salah satu pemecahan masalah ketergantungan terhadap penggunaan pupuk kimia.

\section{METODE PENELITIAN}

Penelitian ini dilaksanakan di Dusun Merjoyo, Desa Sukodadi, Kecamatan Sukodadi, Kabupaten Lamongan. Ketinggian tempat $\pm 6 \mathrm{~m}$ di atas permukaan laut. Waktu penelitian dilaksanakan pada bulan Februari-April dengan $\mathrm{pH}$ 6-7 dengan curah hujan yang berkisar sampai $1.412 \mathrm{~mm}$, Bahan dan alat benih kacang tanah varietas hypoma 1 , Vesicular Arbuscular Micorrhiza (VAM), pupuk phonska, pupuk kimia dan pestisida untuk pengendalian hama dan penyakit. Alat yang digunakan adalah: cangkul, sabit, pisau, timbangan, meteran, penyemprot, gunting, alat-alat tulis dan penunjang lainnya

Penelitian ini menggunakan sebuah metode Rancangan Acak Kelompok RAK Faktorial, Terdiri dari 2 faktor yang diulang 3 kali ulangan,

Yaitu : faktor pertama, dosis micorrhiza terdiri dari 3 level yaitu, $100 \mathrm{~kg} / \mathrm{ha}, 200 \mathrm{~kg} / \mathrm{ha}$ dan $300 \mathrm{~kg} / \mathrm{ha}$. Faktor kedua dosis pupuk phonska terdiri dari 3 level yaitu, tanpa pupuk phonska, $50 \mathrm{~kg} / \mathrm{ha}$, dan $100 \mathrm{~kg} / \mathrm{ha}$.

Penanaman dilakukan dengan cara memasukkan benih kacang tanah pada lubang tanam sedalam $\pm 3 \mathrm{~cm}$ dengan jarak tanam antar lubang $25 \mathrm{~cm} \times 25 \mathrm{~cm}$ dan pengaplikasian mikoriza diberikan satu minggu sebelum penanaman kacang tanah. pupuk yang digunakan diantaranya mikoriza dan pupuk Phonska serta kebutuhan anorganik lainya. Parameter yang diamati antara lain :

a. Tinggi tanaman dilakukan dengan mengukur mulai dari permukaan tanah sampai pucuk tanaman tertinggi.

b. Jumlah daun dihitung yang sudah membuka sempurna, dan pengamatan dimulai pada tanaman berumur 14, 28,42 dan 56 hari setelah tanam.

c. berat brangkasan basah tanaman ditimbang dalam keadaan masih segar per tanaman sampel.

d. berat brangkasan kering tanaman ditimbang ketika sudah dikeringkan dulu, mulai dari akar sampai daun per tanaman sampel.

e. berat biji kering ditimbang berat biji kering tanaman sampel.

\section{HASIL DAN PEMBAHASAN \\ Tinggi Tanaman}

Hasil analisa sidik ragam menunjukkan bahwa terdapat interaksi antara perlakuan dosis vesicular arbuscular micorrhiza dan phonska terhadap tinggi tanaman pada umur 28 hst, 42 hst dan 56 hst. Hal ini dapat dilihat pada Tabel 1.

Pada Tabel 1, dapat dilihat bahwa pengamatan parameter tinggi tanaman menunjukkan interaksi antar perlakuan dosis mikoriza dan phonska. Nilai tertinggi diperoleh pada perlakuan dosis mikoriza 200 $\mathrm{kg} / \mathrm{ha}$ dan phonska $100 \mathrm{~kg} / \mathrm{ha}$. Hal ini karena mikoriza yang menginfeksi perakaran tanaman dapat memproduksi jaringan ekspansif, sehingga meningkatkan kapasitas akar dalam penyerapan unsur hara, terutama fosfat $(P)$.

Mikoriza adalah sekelompok jamur tanah yang bersimbiosis saling menguntungkan dengan akar tanaman atau pohon, agar jamur ini dapat pasokan gula cair dari tanaman, dan sebaliknya jamur ini menukarkan dalam bentuk air dan unsur hara yang diperlukan untuk pertumbuhan tanaman (Saepul, 2006).

\section{Jumlah Daun}

Hasil analisa sidik ragam menunjukkan bahwa terdapat interaksi antara perlakuan dosis vesicular arbuscular micorrhiza dan phonska terhadap jumlah daun pada umur 28 hst, 42 hst dan 56 hst. Hal ini dapat dilihat pada Tabel 2. 
Tabel 1. Rata-rata Tinggi Tanaman $(\mathrm{cm})$ pada Pengamatan Umur 28 Hst, 42 Hst dan 56 Hst

\begin{tabular}{lccc}
\hline \multirow{2}{*}{ Perlakuan } & \multicolumn{3}{c}{ Rata-rata tinggi tanaman (cm) umur } \\
\cline { 2 - 4 } & $28 \mathrm{hst}$ & $42 \mathrm{hst}$ & $56 \mathrm{hst}$ \\
\hline Tanpa phonska + mikoriza $100 \mathrm{~kg} / \mathrm{ha}$ & $19,27 \mathrm{ab}$ & $32,70 \mathrm{~d}$ & $45,40 \mathrm{def}$ \\
\hline Tanpa phonska + mikoriza $200 \mathrm{~kg} / \mathrm{ha}$ & $18,93 \mathrm{bcde}$ & $32,30 \mathrm{~d}$ & $47,33 \mathrm{~cd}$ \\
\hline Tanpa phonska + mikoriza $300 \mathrm{~kg} / \mathrm{ha}$ & $18,27 \mathrm{e}$ & $35,20 \mathrm{~cd}$ & $45,37 \mathrm{def}$ \\
\hline Phonska $50 \mathrm{~kg} / \mathrm{ha}+$ mikoriza $100 \mathrm{~kg} / \mathrm{ha}$ & $18,23 \mathrm{e}$ & $35,77 \mathrm{~cd}$ & $45,60 \mathrm{cdef}$ \\
\hline Phonska $50 \mathrm{~kg} / \mathrm{ha}+$ Mikoriza $200 \mathrm{~kg} / \mathrm{ha}$ & $18,97 \mathrm{bcde}$ & $39,33 \mathrm{ab}$ & $47,93 \mathrm{bc}$ \\
\hline Phonska $50 \mathrm{~kg} / \mathrm{ha}+$ Mikoriza $300 \mathrm{~kg} / \mathrm{ha}$ & $19,23 \mathrm{abc}$ & $34,13 \mathrm{~cd}$ & $46,93 \mathrm{cde}$ \\
\hline Phonska $100 \mathrm{~kg} / \mathrm{ha}+$ Mikoriza $100 \mathrm{~kg} / \mathrm{ha}$ & $18,97 \mathrm{bcde}$ & $36,23 \mathrm{bc}$ & $48,93 \mathrm{ab}$ \\
\hline Phonska $100 \mathrm{~kg} / \mathrm{ha}+$ Mikoriza $200 \mathrm{~kg} / \mathrm{ha}$ & $19,83 \mathrm{a}$ & $39,80 \mathrm{a}$ & $50,20 \mathrm{a}$ \\
\hline Phonska $100 \mathrm{~kg} / \mathrm{ha}+$ Mikoriza $300 \mathrm{~kg} / \mathrm{ha}$ & $19,20 \mathrm{abcd}$ & $35,33 \mathrm{~cd}$ & $42,40 \mathrm{f}$ \\
\hline BNT 5\% & $0,77 \%$ & $3,52 \%$ & 3,31
\end{tabular}

Keterangan : Angka-angka yang diikuti oleh huruf yang sama dalam kolom yang sama tidak berbeda nyata dengan uji BNT 5\%.

Tabel 2. Rata-rata Jumlah Daun (cm) pada Pengamatan Umur 28 Hst, 42 Hst dan 56 Hst.

\begin{tabular}{lccc}
\hline \multirow{2}{*}{ Perlakuan } & \multicolumn{3}{c}{ Rata-rata tinggi tanaman (cm) umur } \\
\cline { 2 - 4 } & $28 \mathrm{hst}$ & $42 \mathrm{hst}$ & $56 \mathrm{hst}$ \\
\hline Tanpa phonska + mikoriza $100 \mathrm{~kg} / \mathrm{ha}$ & $74,07 \mathrm{bcd}$ & $79,63 \mathrm{~d}$ & $127,30 \mathrm{bcde}$ \\
Tanpa phonska + mikoriza $200 \mathrm{~kg} / \mathrm{ha}$ & $68,10 \mathrm{~d}$ & $79,67 \mathrm{~d}$ & $122,23 \mathrm{bcde}$ \\
Tanpa phonska + mikoriza $300 \mathrm{~kg} / \mathrm{ha}$ & $78,20 \mathrm{ab}$ & $84,73 \mathrm{bcd}$ & $131,20 \mathrm{bcde}$ \\
Phonska $50 \mathrm{~kg} / \mathrm{ha}+$ mikoriza $100 \mathrm{~kg} / \mathrm{ha}$ & $76,90 \mathrm{abcd}$ & $91,07 \mathrm{bc}$ & $135,00 \mathrm{abcd}$ \\
Phonska $50 \mathrm{~kg} / \mathrm{ha}+$ Mikoriza $200 \mathrm{~kg} / \mathrm{ha}$ & $75,93 \mathrm{bcd}$ & $85,27 \mathrm{bcd}$ & $133,57 \mathrm{bcde}$ \\
Phonska $50 \mathrm{~kg} / \mathrm{ha}+$ Mikoriza $300 \mathrm{~kg} / \mathrm{ha}$ & $73,60 \mathrm{bcd}$ & $82,53 \mathrm{bcd}$ & $140,53 \mathrm{ab}$ \\
Phonska $100 \mathrm{~kg} / \mathrm{ha}+$ Mikoriza $100 \mathrm{~kg} / \mathrm{ha}$ & $77,27 \mathrm{abc}$ & $93,13 \mathrm{~b}$ & $135,07 \mathrm{abc}$ \\
Phonska $100 \mathrm{~kg} / \mathrm{ha}+$ Mikoriza $200 \mathrm{~kg} / \mathrm{ha}$ & $85,57 \mathrm{a}$ & $104,83 \mathrm{a}$ & $157,20 \mathrm{a}$ \\
Phonska $100 \mathrm{~kg} / \mathrm{ha}+$ Mikoriza $300 \mathrm{~kg} / \mathrm{ha}$ & $73,00 \mathrm{bcd}$ & $88,47 \mathrm{bcd}$ & $115,40 \mathrm{bc}$ \\
\hline BNT 5\% & $8,83 \%$ & $10,73 \%$ & $18,66 \%$
\end{tabular}

Keterangan: Angka-angka yang diikuti oleh huruf yang sama dalam kolom yang sama tidak berbeda nyata dengan uji BNT 5\%.

Pada tabel 2 dapat dilihat bahwa pengamatan parameter jumlah daun yang menunjukkan nilai terbaik terdapat perlakuan dosis mikorizha dan phonska menghasilkan jumlah daun tanaman terbaik pada umur 28 hst yaitu 85,57 helai, umur 42 hst yaitu 104,83 helai, dan pada umur 56 hst yaitu 157,20 helai nilai terbaik didapatkan pada perlakuan dosis phonska $100 \mathrm{~kg} / \mathrm{ha}$ dan dosis mikoriza 200 $\mathrm{kg} / \mathrm{ha}$ karena nilainya tertinggi. Diketahui bahwa dosis pupuk phonska dapat menghasilkan jumlah daun yang lebih baik, hal ini kandungan unsur $\mathrm{N}$ pada pupuk phonska cukup untuk membantu proses pertumbuhan pada masa vegetatif tanaman dan pengaruh asosiasi cendawan dengan akar tanaman tingkat tinggi yang biasa disebut dengan mikoriza yang memanjangkan akar sehingga akar tanaman dapat mengambil semua nutrisi yang ada didalam tanah dengan jarak yang 
panjang sehingga semua kebutuhan nutrisi teroenuhi terhadap kacang tanah. Vesikular arbuskular Mikoriza termasuk salah satu tipe cendawan yang membentuk asosiasi simbiotik mutualis dengan akar tanaman dan berperan dalam meningkatkan absorpsi unsur hara terutama P (Muis, et al., 2013). Pemberian mikoriza endemic dapat menekan penggunaan pupuk kimia hingga 30\%-40\% (Istiqomah et al., 2014).

\section{Berat Brangkasan Basah}

Hasil analisa sidik ragam menunjukkan bahwa terdapat hasil berbeda nyata pada perlakuan dosis mikoriza dan phonska terhadap berat brangkasan basah pada saat panen. Hal ini dapat dilihat pada Tabel 3.

Pada tabel 3, dapat dilihat bahwa pengamatan prameter berat basah tanaman terdapat berbeda nyata pada perlakuan dosis mikoriza pada setiap levelnya dengan hasil terbaik pada perlakuan dosis phonska 100

Tabel 3. Rata-rata Berat Brangkasan Basah (gram)

\begin{tabular}{cc}
\hline Perlakuan & Rata-rata Berat Brangkasan Basah (gram) \\
\hline Tanpa phonska & $218,99 \mathrm{ab}$ \\
Phonska $50 \mathrm{~kg} / \mathrm{ha}$ & $215,55 \mathrm{c}$ \\
Phonska $100 \mathrm{~kg} / \mathrm{ha}$ & $221,20 \mathrm{a}$ \\
\hline BNT 5\% & $\mathbf{2 , 5 0}$ \\
\hline Mikoriza $100 \mathrm{~kg} / \mathrm{ha}$ & $216,37 \mathrm{~b}$ \\
Mikoriza $200 \mathrm{~kg} / \mathrm{ha}$ & $223,45 \mathrm{a}$ \\
Mikoriza $300 \mathrm{~kg} / \mathrm{ha}$ & $215,93 \mathrm{~b}$ \\
\hline BNT 5\% & $\mathbf{2 , 5 0}$ \\
\hline
\end{tabular}

Keterangan : Angka-angka yang diikuti oleh huruf yang sama dalam kolom yang sama tidak berbeda nyata dengan uji BNT $5 \%$.

\section{Berat Brangkasan Kering}

Hasil analisa sidik ragam menunjukkan bahwa terdapat interaksi pada perlakuan dosis mikoriza dan phonska terhadap berat brangkasan kering pada saat panen. Hal ini dapat dilihat pada Tabel 4.

Pada Tabel 4, dapat dilihat bahwa pengamatan parameter berat brangkasan kering menunjukkan interaksi antar perlakuan dosis mikoriza dan phonska. Nilai tertinggi $\mathrm{kg} / \mathrm{ha}$ dan dosis mikoriza $200 \mathrm{~kg} / \mathrm{ha}$ memberikan hasil terbaik ditunjukkan degan hasil yang lebih tinggi.

Hal ini diduga disebabkan karena media tanam yang harus digunakan sudah mengandung jamur mikoriza namun penambahan mikroriza belum mampu menginfeksi akar secara maksimal sehingga tidak mempengaruhi pertumbuhan generatif tanaman untuk membentuk biji sebagai hasil proses fotosintesis. Hasil penelitian ini sejalan dengan Damanik, et al. (2013) bahwa pemberian mikoriza sebanyak $10 \mathrm{~g} /$ tanaman tidak berpengaruh terhadap jumlah polong berisi, jumlah polong hampa, bobot biji per tanaman dan bobot 100 biji. Hasil penelitian ini berbeda dengan hasil penelitian oleh Zuhri dan Puspita (2008) yaitu bahwa pemberian mikoriza 40g/tanaman mampu meningkatkan jumlah polong dan bobot biji kering/tanaman. 
Tabel 4. Rata-rata Berat Brangkasan Kering (gram)

Perlakuan

Rata-rata Berat Brangkasan Kering (gram)

\begin{tabular}{lc}
\hline Tanpa phonska + mikoriza $100 \mathrm{~kg} / \mathrm{ha}$ & $32,18 \mathrm{cde}$ \\
Tanpa phonska + mikoriza $200 \mathrm{~kg} / \mathrm{ha}$ & $33,55 \mathrm{bcd}$ \\
Tanpa phonska + mikoriza $300 \mathrm{~kg} / \mathrm{ha}$ & $31,93 \mathrm{cdef}$ \\
Phonska $50 \mathrm{~kg} / \mathrm{ha}+$ mikoriza $100 \mathrm{~kg} / \mathrm{ha}$ & $33,67 \mathrm{bc}$ \\
Phonska $50 \mathrm{~kg} / \mathrm{ha}+$ Mikoriza $200 \mathrm{~kg} / \mathrm{ha}$ & $32,05 \mathrm{cdef}$ \\
Phonska $50 \mathrm{~kg} / \mathrm{ha}+$ Mikoriza $300 \mathrm{~kg} / \mathrm{ha}$ & $33,73 \mathrm{ab}$ \\
Phonska $100 \mathrm{~kg} / \mathrm{ha}+$ Mikoriza $100 \mathrm{~kg} / \mathrm{ha}$ & $31,18 \mathrm{f}$ \\
Phonska $100 \mathrm{~kg} / \mathrm{ha}+$ Mikoriza $200 \mathrm{~kg} / \mathrm{ha}$ & $35,53 \mathrm{a}$ \\
Phonska $100 \mathrm{~kg} / \mathrm{ha}+$ Mikoriza $300 \mathrm{~kg} / \mathrm{ha}$ & $34,13 \mathrm{ab}$ \\
\hline BNT 5\% & $\mathbf{1 , 8 4}$
\end{tabular}

Keterangan : Angka-angka yang diikuti oleh huruf yang sama dalam kolom yang sama tidak berbeda nyata pada taraf Uji BNT $5 \%$.

Berat Biji Per Petak

Hasil analisa sidik ragam

pada perlakuan pemberian dosis phonska menunjukkan bahwa terdapat hasil beda nyata terhadap berat biji per petak. Hal ini dapat dilihat pada Tabel 5 .

Tabel 5. Rata-rata Berat Biji Perpetak (g).

\begin{tabular}{cc}
\hline \multicolumn{1}{c}{ Perlakuan } & Rata-rata Berat Biji Per Petak (g) \\
\hline Tanpa phonska & $157,00 \mathrm{c}$ \\
Phonska $50 \mathrm{~kg} / \mathrm{ha}$ & $164,00 \mathrm{~b}$ \\
`Phonska $100 \mathrm{~kg} / \mathrm{ha}$ & $184,67 \mathrm{a}$ \\
\hline BNT 5\% & $\mathbf{6 , 3 4}$ \\
\hline
\end{tabular}

Keterangan : Angka-angka yang diikuti oleh huruf yang sama dalam kolom yang sama tidak berbeda nyata dengan uji BNT 5\%.

Pada tabel 5 dapat dilihat bahwa nilai terbaik rata-rata berat biji perpetak diperoleh dari perlakuan phonska yang berbobot 185,20 gr bahwa terdapat hasil berbeda nyata pada perlakuan dosis phonska terhadap berat biji per petak pada setiap pengamatan, dengan hasil terbaik pada perlakuan dosis phonska 100 $\mathrm{kg} / \mathrm{ha}$.

\section{SIMPULAN}

Pada fase vegetatif menunjukkan terjadinya interaksi antara perlakuan dosis mikoriza dan phonska pada parameter tinggi tanaman pada umur 28, 42, dan 56 hari setelah tanam. Sedangkan pada fase generatif terjadi pada parameter jumlah daun, dan berat kering tanaman. Perlakuan terbaik didapatkan pada perlakuan dosis phonska $100 \mathrm{~kg} / \mathrm{ha}$ dan mikoriza $200 \mathrm{~kg} / \mathrm{ha}$. Perlakuan dosis mikoriza $200 \mathrm{~kg} / \mathrm{ha}$ dan phonska $100 \mathrm{~kg} / \mathrm{ha}$ menghasilkan nilai yang lebih baik dibandingkan perlakuan lainnya. 


\section{DAFTAR PUSTAKA}

Anonimous. 2013. Cara budidaya kacang tanah organik. http://www.alamtani.com/budidayakacang-tanah-organik.html. Diakses tanggal 10 Desember 2013

Damanik, A.F., Rosmayati dan H. Hasyim. 2013. Respon Pertumbuhan dan Produksi Kedelai terhadap Pemberian Mikoriza dan Penggunaan Ukuran Biji pada Tanah Salin. dikuti Jurnal Online Agroekoteknologi, I(2):142-153.

Fitrianto, Hermanto dan H. Kriswantoro.2014. Studi Pemanfaatan Mikoriza Arbuskular dan Efisiensi Pupuk Phospatterhadap Pertumbuhan dan Produksi Tanaman Kacang Hijau (Phaseolus radiatus L) Pada Tanah PMK. Prosiding Seminar Nasional Lahan Suboptimal, Palembang. HIm : 124-132.

Istiqomah, I., Sastrahidayat, I.R., Muhibuddin,

$$
\begin{aligned}
& \text { A., 2014. PENGARUH PENGGUNAAN } \\
& \text { INANG PERANTARA PADI GOGO } \\
& \text { TERHADAP POPULASI MIKORIZA DAN } \\
& \text { INTENSITAS SERANGAN PENYAKIT REBAH } \\
& \text { SEMAI (Sclerotium rolfsii) PADA KEDELAI } \\
& \text { (Glycine max L.). J. Hama dan Penyakit } \\
& \text { Tumbuh. 2, pp-54. }
\end{aligned}
$$

Kristina N. 2016. Pengaruh Pemberian Pupuk NT45 dan Pupuk Fosfat Terhadap Pertumbuhan dan Hasil Tanaman Kacang Tanah. Skripsi. Fakultas Pertanian Universitas Andalas. Sumatera Barat. (tidak publikasi).

Maryani, A.T. Dan Nelvia 2009. Efek Beberapa Sumber Fosfat Dan Mikoriza Vescular Arbuscular Pada Bibit Tanaman Jarak Pagar Di Medium Gambut. Jurnal Fakultas Pertanian Universitas Riau 8 (2) : 1-7.

Muis, A., D. Indradewa dan J. Widada. 2013. Pengaruh Inokulasi Mikoriza terhadap Pertumbuhan dan hasil Kedelai (Glicyne max (L) Merrill) pada Berbagai Interval Penyiraman. Vegetalika, 2(2): 7-20.
Mulyani A. 2006. Potensi Lahan Kering Masam untuk Pengembangan Pertanian. Warta Penelitian dan Pengembangan Pertanian. 28 (2) : 16 - 17.

Saepul, U.Y. (2006). Penggunaan Cendawan Mikoriza Arbuskular (CMA) untuk Meningkatkan Pertumbuhan Semai Jati (Tectona Grandis Linn. F.) pada Limbah Media Tumbuh Jamur Tiram (Pleurotus sp.). Bogor: Program Studi Budidaya Hutan Fakultas Kehutanan Institut Pertanian Bogor.

Siregar S.H., Lisa M., dan T. Irmansyah. 2017. Pertumbuhan dan Produksi Kacang Tanah (Arachis hyppogea L.) dengan beberapa sistem Olah Tanah dan Asosiasi Mikrobia. Jurnal Online Agroteknologi. 5 (1): 202-207.

Sudiarso. 2007. Pupuk Organik dalam Sistem Pertanian Berkelanjutan. Fakultas Pertanian Universitas Brawijaya. Malang. Cetakan Pertama. $264 \mathrm{~h}$.

Talanca, Haris. 2010. Status Cendawan Mikoriza Vesikular Arbuskular (MVA) Pada Tanaman. Prosiding Pekan Serealia Nasional. Balai Penelitian Tanaman Serealia, Sulawesi Selatan.

Taufiq A. dan Kristono, A. 2015. Keharaan Tanaman Kacang Tanah. Balai Penelitian Tanaman Aneka Kacang dan Umbi. Monograf Balitkabi No. 13. Hal. $170-193$.

Zuhri, E. dan F. Puspita. 2008. Pemberian Cendawan Mikoriza Arbuskular (CMA) pada Tanah Podzolik Merah Kuning (PMK) terhadap Pertumbuhan dan Produksi Kedelai (Glycine max (L) Merrill). Jurnal Sagu,7 (2). 